\title{
Soft computing techniques and applications for intelligent multimedia systems
}

Published online: 3 September 2019

(C) Springer Science+Business Media, LLC, part of Springer Nature 2019

Multimedia Tools and Applications gratefully acknowledges the editorial work of the scholars listed below on the special issue entitled "Soft Computing Techniques and Applications for Intelligent Multimedia Systems."

Of 35 papers submitted to this issue, 7 were eventually accepted after a stringent peer-review process.

\section{Corresponding Guest Editor.}

Dr. Vijayakumar Varadarajan

School of Computing Sciences and Engineering, VIT University, India

Email: vijayakumar.v@vit.ac.in

\section{Guest Editors}

\section{Dr. Subramaniyaswamy V}

School of Computing, Sastra University, India

Email: vsubramaniyaswamy@gmail.com

\section{Dr. Longzhi Yang}

Department of Computer and Information Sciences, Northumbria University, UK

Email: longzhi.yang@northumbria.ac.uk

\section{Dr. Jemal Abawajy}

School of Information Technology, Deakin University, Australia

Email: jemal.abawajy@deakin.edu.au

Pulisher's note Springer Nature remains neutral with regard to jurisdictional claims in published maps and institutional affiliations 